Man and Nature

MAN AND NATURE

L'homme et la nature

L'HOMME ET LA NATURE

\title{
Voltaire's Reaction to Maupertuis's Lettre sur le progrès des sciences
}

\section{Margarete G. Smith}

Volume 7, 1988

URI : https://id.erudit.org/iderudit/1011933ar

DOI : https://doi.org/10.7202/1011933ar

Aller au sommaire du numéro

Éditeur(s)

Canadian Society for Eighteenth-Century Studies / Société canadienne d'étude du dix-huitième siècle

ISSN

0824-3298 (imprimé)

1927-8810 (numérique)

Découvrir la revue

Citer cet article

Smith, M. G. (1988). Voltaire's Reaction to Maupertuis's Lettre sur le progrès des sciences. Man and Nature / L'homme et la nature, 7, 159-166.

https://doi.org/10.7202/1011933ar

Copyright (C) Canadian Society for Eighteenth-Century Studies / Sociéte canadienne d'étude du dix-huitième siècle, 1988
Ce document est protégé par la loi sur le droit d'auteur. L’utilisation des services d'Érudit (y compris la reproduction) est assujettie à sa politique d'utilisation que vous pouvez consulter en ligne.

https://apropos.erudit.org/fr/usagers/politique-dutilisation/ 


\section{Voltaire's Reaction to Maupertuis's Lettre sur le progrès des sciences}

Maupertuis's Lettre sur le progrès des sciences appeared in print in the summer of 1752, at the height of his dispute with Samuel König, a fellow mathematician, who had detected flaws in Maupertuis's principle of least action as expounded in the latter's Cosmologie. Finding it somewhat difficult myself to comprehend the contentious issue which destroyed the once friendly relationship between these two opinionated mathematicians, ${ }^{1}$ I leave it to Voltaire's witty pen to supply the necessary background. In July of 1752 he wrote to his niece Mme Denis:

Quant à la querelle de Maupertuis et de Koenig, en voici le sujet. Ce Koenig est amoureux d'un problème de géométrie, comme les anciens paladins de leurs dames. Il fit l'année passée le voyage de la Haye à Berlin uniquement pour aller conférer avec Maupertuis sur une formule d'algèbre et sur une loi de la nature dont vous ne vous souciez guère. Il lui montra deux lettres d'un vieux philosophe du siècle passé, nommé Leibnitz, dont vous ne vous souciez pas davantage; et lui fit voir que Leibnitz avait parlé de la même loi et combattait son sentiment.... Le professeur de la Haye lui demanda permission d'exposer son opinion dans les journaux de Leipsick, et avec cette permission il réfuta le plus poliment du monde dans ces journaux l'opinion de Maupertuis....

Maupertuis ayant parcouru et mal lu ce journal de Leipsick et ces fragments de Leibnitz alla se mettre dans la tête que Leibnitz était de son opinion, et que Koenig avait forgé ces lettres pour lui ravir, à lui Maupertuis, la gloire d'avoir inventé une bévue. Sur ce beau fondement il fait assembler les académiciens pensionnaires dont il distribue les gages. Il accuse formellement Koenig d'être un faussaire et fait passer un jugement contre lui sans que personne opine.... On ne laisse pas de voir des choses nouvelles sous le soleil. On n'avait point encore vu de procès criminel dans une académie des sciences. (Best. D.4956)

In spite of his initial intention of refraining from becoming embroiled in this controversy, Voltaire could not miss this opportunity to chastise Maupertuis, the one Frenchman in Frederick's entourage he could not suffer. 
It is difficult to understand why Voltaire, during his stay in Berlin, conceived such hatred against this man who was once his friend and tutor, for it was Maupertuis who, twenty years earlier, had helped not only Mme du Châtelet at Cirey, but also Voltaire to master Newtonian physics before the latter had sufficient confidence to attempt its dissemination in a skeptical France. Unfortunately, Mme du Châtelet's attachment to Maupertuis did not remain on a purely intellectual level. She became his mistress at a time when Voltaire was still in love with her. This caused some resentment even in the open-minded Voltaire and the fact that Madame du Châtelet's amorous involvements with other prominent men were well-known at Frederick's court must have been a constant source of embarrassment to Voltaire.

It is also quite possible that Voltaire rose to the defense of König because his sense of justice was so outraged that he had to lend his full support to a victim of academic persecution. Yet, as Formey pointed out in his Souvenirs, ${ }^{2}$ Voltaire, whose mathematical competence was minimal, was in no position to pass judgment on this scientific controversy. However, this is precisely what Voltaire did, although he was aware of the fact that Euler, probably the only mathematician competent in this abstract matter, fully supported Maupertuis's view. In July of 1752 Voltaire wrote to Formey: 'Je vous dirai en passant que quelquefois ceux qu'on avait pris pour des aigles, ne sont que des coqs $d^{\prime}$ Inde; qu'un orgueil despotique, avec très peu de science, et beaucoup de ridicule, est bientôt reconnu et détesté de l'Europe savante' (Best. D.4934).

And in January 1753 Voltaire sent a note in English to his friend Sir Everard Fawkener:

You must know that a dispute upon a point of mathematics hath rais'd a scandalous noise between one Maupertuis, president of the prussian academy, and the professor Koenig. All the philosofers of Europe were for Koenig, and all the world cry'd out against the ill usage he receiv'ed from Maupertuis.... In the mean time Maupertuis gave out a singular book of philosophy. The author proposes to build a latin town; to lengthen out human life to four hundred years, by laying men asleep; to go to the antartik pole, and there to dissect the brain of giants in order to know the nature of the soul, etc. The book is full of such nonsense: but the author had the good sense to calumniate me to the king. His majesty one day according to his good will and pleasure, order'd at his break fast that his own hang man should burn a little banter $j$ had writ upon the noble discoverings of Maupertuis. The rest of the story is contain'd in the little paper $j$ send you, which $j$ intreat you to make appear in all $y^{r}$ news papers. If $j$ live, if $j$ am free, i'll cross the sea to thank you. (Best. d.5160) 
Once embarked on the defence of König, nothing could have pleased Voltaire more than the surprise appearance of Maupertuis's Lettre sur le progrès des sciences ${ }^{3}$ which supplied Voltaire with all the satirical material he needed to ridicule the president of Frederick's Academy. This letter on the progress of the sciences must have struck an ordinary eighteenth-century citizen like modern science fiction. Many of the subjects examined were far ahead of their time and it is no wonder that ever the great Voltaire perceived them as the offspring of a deranged mind. Yet many of Maupertuis's suggestions have now come to fruition and it is Voltaire's satirical comments upon Maupertuis's scientific intuition which strike us as trivial.

Maupertuis's letter was intended to indicate to Frederick practical areas of research deserving of financial support. For instance, expeditions could be organized to explore the unknown interiors of Australia and Africa, not only for their economic potential, but also for the study of their exotic fauna and their tribal inhabitants. Australia, in particular, on account of its isolation from other continents, could provide valuable information in helping to understand our physical and social environment. Strange tales from travellers about giants and other creatures covered in fur and possessing tails should be investigated. The search for a North West Passage should be continued. Two or three ships could be sent annually to explore polar regions. Scientists could accompany these ships to pursue further research on magnetism.

Maupertuis would like to see the establishment of an international academy for the exchange of new knowledge accumulated in all countries of the world. For a quick and efficient dissemination of knowledge a universal language is needed. Most scientific treatises are still presented in Latin. To facilitate acquisition of this language, Maupertuis proposes an immersion-type environment where only Latin is spoken and the bright children of all nations are educated.

Maupertuis also encourages astronomers to co-ordinate their efforts in the exploration of the heavens totally unknown to man. Each country should be assigned one region of the sky for study. Telescopes must be perfected for this purpose. On a small scale the use of the microscope would reveal a new world, enabling scientists to unravel many phenomena. Buffon and Needham had already shown the way.

With the physical sciences progressing at such an unprecedented speed, Maupertuis regretted that medicine lagged behind the times. Consequently, he had some bold proposals with regard to improvements in medical science.

Pursuing La Mettrie's theory that quality of life could be considerably improved by a scientifically trained medical personnel, Maupertuis proposed the testing of a variety of drugs on animals and criminals 
for the relief and cure of many ailments. He considered the medical profession too conservative and too timid. For instance, some diseased but not vitally important organs could be removed to save life. Specialists needed to be trained for these delicate operations. As the human body is a complicated machine, one doctor cannot adequately see to all its needs.

Certain unconventional treatments practised by the Japanese and Egyptians should not be rejected as absurd or dangerous. They may have some validity and should therefore be tested. Maupertuis, a disciple of empirical science, advocates a practical approach to medicine: 'Le meilleur Médecin est celui qui raisonne le moins, qui observe le plus' (NBG, x, 350).

As a keen biologist, Maupertuis has also some advice for naturalists. Simply classifying plants and beasts is of little value. He explains: 'Pour faire de l'Histoire Naturelle une véritable Science, il faudroit qu'on s'appliquât à des recherches qui nous fissent connoître, non la figure particulière de tel ou tel Animal, mais les procédés généraux de la Nature dans sa production et sa conservation' (NBG, x, 351).

Maupertuis was fascinated by genetics and he was probably the first scientist to propose that the appearance of new species may result from mutations. He also advocated artifical insemination where natural conception was impossible. As he explained in his letter:

On pourroit d'abord tenter sur une même Espéce ces unions artificielles; et peut-être dès la première fois rendroit-on en quelque sorte la fécondité à des Individus, qui par les moyens ordinaires paroissent stériles. Mais on pourroit encore pousser plus loin les expériences, et jusque sur les Espéces que la $\mathrm{Na}$ ture porte le moins à s'unir. On verroit peut-être même des Espéces entiéres, que la Nature n'a pas encore produites. (NBG, x, 353)

Maupertuis, like other eighteenth-century philosophes, was preoccupied with the body-mind connection and in his letter suggests that experiments with certain drugs might reveal their effect on the mind. With the right drug abnormal behaviour could perhaps be corrected. He advocated this very modern approach for a better understanding of the functioning of the mind by observing sense stimulation on the brain of a live person - criminals should be used for such experiments, but only with their full consent: 'Qu'on ne se laisse point émouvoir par l'air de cruauté qu'on pourroit croire trouver ici: un Homme n'est rien, comparé à l'Espèce humaine; un Criminel est encore moins que rien' (NBG, $x, 346$ ).

Maupertuis was the first to admit that some of his ideas were eccentric (for instance, like digging to the centre of the earth to discover the 
composition of our planet's interior), but in order to make scientific progress, extra-ordinary steps had to be taken and one should allow one's imagination to run wild.

Maupertuis's proposals span a wide horizon: geography, astronomy, mathematics, physics, medicine, natural history and genetics and they show that almost every branch of knowledge was within his grasp. Intellectually, he was probably superior to Voltaire, yet it was Voltaire's narrow-minded sarcasm that succeeded in destroying this genius.

Voltaire could have pursued some legitimate criticism. For instance, Maupertuis's advocacy of using criminals for medical research may shock a modern reader, but Voltaire was not overly concerned about this proposal. He simply dismissed it as unoriginal since criminals in the past had already been exploited for such purposes and Voltaire obviously saw no harm in this practice. As he writes in the Akakia:

Il ignore ce que tout le monde sait, que du temps de Louis XI on fit pour la première fois en France, sur un homme condamné à mort, l'épreuve de la taille; que la feue reine d'Angleterre fit essayer l'inoculation de la petite vérole sur quatre criminels, et qu'il y a d'autres exemples pareils. (M.xxiii, 563)

Nor did Voltaire raise a cry of protest against Maupertuis's inhuman proposal to isolate some children from birth for the purpose of studying the development of language and of observing the formation of basic human ideas and concepts. Apparently such cruelty elicited no protest from Voltaire. Instead, he selected a few of Maupertuis's somewhat odd statements and cleverly exploited them ad infinitem, first in the Akakia, then in almost every letter to friends from his Berlin residence. He twisted them in such a manner in order to convince his readers that he confronted them with the hallucinations of a deranged mind. Ridicule was an effective weapon to eliminate those he thoroughly dislike. To Mme Denis he wrote:

Je n'ai point de sceptre, mais j'ai une plume, et j'avais, je ne sais comment, taillé cette plume de façon qu'elle a tourné un peu Platon en ridicule sur ses géants, sur ses prédictions, sur ses dissections, sur son impertinente querelle avec Koenig. (Best, D. 5067)

May I quote two Voltairian letters which summarize the content of the Akakia? In November of 1752 he wrote to Samuel König:

On m'apporte un volume de lettres que Maupertuis a fait imprimer il y a un mois; je ne peux plus que le plaindre; il n'y a plus à se fâcher. C'est un homme qui prétend que pour mieux connaître la nature de l'âme, il faut aller aux terres 
australes disséquer des cerveaux de géants hauts de douze pieds, et des hommes velus portant une queue de singe. Il veut qu'on enivre les gens avec de l'opium pour épier dans leurs rêves les ressorts de l'entendement humain. Il propose de faire un grand trou qui pénètre jusqu'au noyau de la terre.... Tout son livre est plein d'un bout à l'autre d'idées de cette force. Ne vous étonnez donc pius de rien. Il travaillait à ce livre lorsqu'il vous persécutait. (Best. D. 5076)

\section{And a few days latter Voltaire wrote to the Duke of Richelieu:}

Maupertuis à force de boire de l'eau de vie s'est mis à la mort, mais il en réchappe parce qu'il est né avec un tempérament de tartare. Il n'est que fou; il vient de faire un livre, où il propose de faire des trous qui aillent jusqu'au centre de la terre, d'aller droit sous le pôle, de connaître le siège de l'âme en disséquant des têtes de géants, ou en examinant les rêves de ceux qui ont pris de l'opium. Il assure qu'il est aussi facile de voir l'avenir que de se représenter le passé, et nous nous attendons que dans quelques jours il débitera des proféties. J'ay eu bien raison de dire en parlant de Descartes, que la géométrie laisse l'esprit comme elle le trouve. Il propose sérieusement de faire vivre les hommes huit à neuf cent ans en les conservant comme des oeufs qu'on empêche d'éclore. Tout est dans ce goust dans son livre. Lamétrie en comparaison a écrit en sage. (Best. D. 5084)

As one reads these constant sarcastic missives one has the distinct impression that Voltaire looked upon himself as a sort of divine messenger called upon to mete out justice and he is tremendously proud and satisfied of his success, of which Formey, secretary of the Berlin Academy, is the first to hear:

Voulez vous une autre anecdote? On a vendu à Paris six mille Akakia en un jour; et le plus orgueilleux de tous les hommes est le plus bafoué. Il n'a que ce que son insolence et ses manœuvres méritent. Et il n'y a personne sans exception auprès de qui il ne soit démasqué. Il aurait dû ne pas me pousser à bout. Je ne suis pas esclave. Soyez homme. (Best. D. 5163)

I do not think that Voltaire's ferocious attack on Maupertuis stemmed solely from a personal dislike of the man, as Formey would like to believe when he recounts the events of the Akakia in his Souvenirs. Maupertuis's work, like the work of so many other eighteenth-century scientists, revealed a universe that had no need of a maker or sustainer. This is one important aspect which Voltaire satirized in the Akakia:

Nous avons, après avoir invoqué le Saint-Esprit, trouvé dans les œuvres ... force propositions téméraires, malsonnantes, hérétiques et sentant l'hérésie. 
Nous les condamnons collectivement, séparément, et respectivement. ... Il écrivit contre les médecins et contre les preuves de l'existence de Dieu. (Mxxiii, $565,560)$

To Samuel Koenig Voltaire wrote:

Rien n'annonce plus la décadence de ce siècle où tout s'est affaibli, parce qu'on a voulu tout outrer. (Best. D. 5230)

These words are indicative of Voltaire's state of mind during the Akakia episode and we detect beneath the burlesque satire of the Akakia a trace of concern, an urgent need to ridicule relentlessly the rash propositions of those mad, irresponsible scientists whose discoveries might reveal a universe lacking a divinity. By satirizing them mercilessly, no one will take them seriously and mankind will be saved from their dangerous knowledge.

And, of course, in Maupertuis's case Voltaire had succeeded. Maupertuis, a proud man, could not survive the satire which had tarnished his reputation as a serious scientist throughout Europe. He gave up his position as President of the Berlin Academy and settled in Basle where he died, a broken man, in 1759. Maupertuis's last letter in Formey is testimony to the suffering Voltaire had inflicted on his victim by his ferocious pen:

Je n'ai point, comme vous, dans ma maladie la ressource du travail: le genre de ma maladie ne le permet point; je n'ai d'autre ressource que celle de mes oiseaux; et ce n'est pas la plus mauvaise compagnie que l'on puisse avoir. D'ailleurs je suis assez dégoûté des sciences et des lettres: et je suis ici bien placé pour cela; car tout le monde y en fait encore moins de cas que moi. (13 March, 1759, in Souvenirs d'un citoyen, i, 190-91)

MARGARETE G. SMITH

Memorial University of Newfoundland 


\section{Notes}

1 See introduction by Jacques Tuffet, included in his critical edition of Voltaire's Histoire du Docteur Akakia et du natif de Saint-Malo (Paris, 1967); also 'L'Akakia.' Ed. Ch. Fleischauer. Studies on Voltaire, Vol. 30 (1964), 7-145.

2 Jean-Henri-Samuel Formey, Souvenirs d'un citoyen (Berlin, 1789), i, 172-83; also Eloge de M. de Maupertuis (Berlin, 1760).

3 Formey published in its entirety Maupertuis's 'Lettre sur le progrès des sciences' in the Nouvelle Bibliothèque germanique (1752) from which we shall quote. 